\title{
Evaluation of Anthropogenic Air Emissions from Marine Engines in a Coastal Urban Airshed of Texas
}

\author{
Zuber M. Farooqui, Kuruvilla John*, Neelesh Sule \\ Department of Mechanical and Energy Engineering, University of North Texas, Denton, USA. \\ Email: *kuruvilla.john@unt.edu \\ Received January $30^{\text {th }}, 2013$; revised March $4^{\text {th }}, 2013$; accepted April $2^{\text {nd }}, 2013$ \\ Copyright (C) 2013 Zuber M. Farooqui et al. This is an open access article distributed under the Creative Commons Attribution Li- \\ cense, which permits unrestricted use, distribution, and reproduction in any medium, provided the original work is properly cited.
}

\begin{abstract}
Corpus Christi, Texas, is a growing urban area with a busy port and a petrochemical industrial base that is currently in compliance with the US Environmental Protection Agency's (EPA) National Ambient Air Quality Standards (NAAQS) for ozone. However, the Texas Commission on Environmental Quality (TCEQ) has classified this urban airshed as a near non-attainment area. A comprehensive annual air emission inventory based on marine engines activity was developed for the years of 2006-2009 for the Port of Corpus Christi, Texas using recent EPA approved methodology. A regional-scale photochemical model Comprehensive Air Modeling system with extensions (CAMx) was used to evaluate the impact of these emissions on the ground level ozone concentrations by zeroing out the emissions and employing Direct Decoupled Method (DDM) for sensitivity analysis to estimate the 8-hour ozone sensitivity coefficients due to $\mathrm{NO}_{\mathrm{x}}$ and $\mathrm{VOC}$ emissions from marine engines. The analysis has shown a localized increase of up to $7.8 \mathrm{ppb}$ in the 8hour ozone concentration very close to the port premises and a decrease of about $1.73 \mathrm{ppb}$ further downwind. Ozone sensitivity analysis using DDM on the 8-hour ozone concentrations showed a higher sensitivity to $\mathrm{NO}_{\mathrm{x}}$ emissions. Thus, any $\mathrm{NO}_{\mathrm{x}}$ related controls of marine engines will benefit local urban and regional ozone levels.
\end{abstract}

Keywords: Marine Engine Emissions; Ozone; Photochemical Modeling; Port Air Quality Management

\section{Introduction}

Over the past few decades, the impact of air emissions from marine engines has gained importance in United States and across the world. Emissions from ocean going vessels (OGV) have become significant sources of air pollutants in urban areas with port infrastructure. OGV are highly polluting combustion sources based on the quantity and quality of fuel consumed [1]. Impact of marine engine emissions is both a local as well as a regional problem. OGV emissions are easily transported through air from sea to land and among continents [2]. International fleets contribute significantly to global anthropogenic emissions [3-4]. Several prior studies have highlighted the development of marine emissions inventory at port facilities and have also provided emission factors for OGV at ports around the world [5-13]. Most of the marine engines are diesel operated and the anthropogenic emissions from diesel exhaust contain air toxics which have adverse effects to the human health and the environment [14-15]. Marine engines are a major non-road

${ }^{*}$ Corresponding author. source category and they are also significant emitters of ozone precursors such as oxides of nitrogen $\left(\mathrm{NO}_{\mathrm{x}}\right)$ and volatile organic compounds (VOC) [16].

It is well-known that all non-road emission inventories have very large uncertainties. The non-road inventories have suffered from two important weaknesses. These weaknesses arise from the assumptions made while developing inventories that are often derived from engineering or manufacturer test data rather than in-service sampling and emission factors from fuel consumption and activities level information that represent a national average which may not be characteristic of emissions at the local level [17]. Therefore, it becomes essential to adopt recently developed emission factors and emission estimation methodologies to minimize these uncertainties.

According to the US Environment Protection Agency (EPA), over the next few decades, marine engine emissions may be significant contributor to the emissions inventory [18]. As per the EPA, all the ports in United States should develop their own activity-based emissions inventory. The emissions inventory developed is used to 
assist local and state implementation plans (SIP) in order to maintain an urban airshed in attainment of the National Ambient Air Quality Standards (NAAQS) for a criteria pollutant such as ozone. The emissions inventory is also built for photochemical modeling purpose that is eventually used for air quality research, planning and management activities. Ozone precursor emissions $\left(\mathrm{NO}_{\mathrm{x}}\right.$ and VOC) from OGV and barges are considered to be significant non-road mobile sources in any coastal urban airshed. It has been shown that nitrogen emissions from OGV account for more than $14 \%$ of all nitrogen emissions from fossil fuel combustion [9]. It was found that in 2002, nonroad sources of emissions contributed 49 tons. day $^{-1}$, approximately $25 \%$ of the total $\mathrm{NO}_{\mathrm{x}}$ emissions within the Corpus Christi urban area in Texas [19].

Corpus Christi is a semi-arid coastal urban area located in South Texas along the Gulf of Mexico. It is home to the sixth largest port in the United States in total tonnage. The presence of the port has facilitated the development of large industrial complexes of chemical and petrochemical industries around its vicinity which also contributes emissions of ozone precursors into the urban atmosphere. Currently Corpus Christi is in attainment of the National Ambient Air Quality Standards (NAAQS) for the 8-hour ozone concentration. However, due to several recent high ozone episodes over the past decade, it has been classified as a near non-attainment area as per the Texas Commission on Environmental Quality (TCEQ). High ozone episodes were observed during 1995, 1999, and 2002. Photochemical modeling for high ozone episodes was conducted for all of these episodes. The most recent photochemical modeling episode developed for the region was for 2002 [19] and this has been used in this study.

The objective of this study was to quantify and assess the emissions from key categories of non-road mobile sources including OGV and barges in the Corpus Christi urban area. This paper will provide a brief description of the adopted methodology for estimating anthropogenic emission estimation of $\mathrm{OGV}$ and barges. It will also demonstrate an assessment of vessels traffic, emissions, and evaluate the impact of marine emissions on urban ozone levels using a photochemical model. To quantify the emissions, ship-specific activity, engine characteristics [20], emission factors, and OGV traffic information was collected from the Port of Corpus Christi. Vesselsspecific information was needed because each vessel entering and leaving the Corpus Christi ship channel (CCSC) has a unique activity profile (cruising, reduced speed zone, docking/hoteling, etc.) and a unique set of emission factors based on the size of the ship, its engine specifications, and its activity profile while operating within the CCSC.

Another objective of the study was to determine the impact of ozone precursors from OGV and barges to the urban ozone levels. Prior studies have demonstrated the influence of $\mathrm{NO}_{\mathrm{x}}$ emissions from OGVs on the tropospheric ozone levels [21-23]. Quantified emissions were processed to generate photochemical model ready inputs to simulate a high ozone episode of September 11-14, 2002. A regional-scale photochemical model Comprehensive Air Modeling system with extensions (CAMx) was used in this study [24]. The modeling exercise was conducted to evaluate the impact of quantified marine emissions and emission sensitivity due to hoteling emissions on the ozone levels within and around the airshed. Several "zero-out" emissions scenarios were simulated to evaluate the influence of emissions from OGV and barges. The photochemical model was also used to determine $\mathrm{NO}_{\mathrm{x}}$ and VOC sensitivity coefficients due to emissions from OGV and barges using a direct decoupled method (DDM). DDM is a stable and computationally efficient tool which integrates the sensitivity equation, decoupled from the model equations [25].

The Corpus Christi ship channel is classified into four traffic segments as shown in Figure $\mathbf{1}$ and these are described in Table 1. Once the marine vessel comes within the port limits it needs to follow the maritime guidelines of the port. An OGV's activities are based on its speed within the segments classified as: cruising, reduced speed zone, maneuvering, and hoteling. In the first segment, OGV enter the ship channel while traveling at cruising speeds not exceeding 20 knots $\left(10.29 \mathrm{~m} \cdot \mathrm{s}^{-1}\right)$. The length of this segment is 3.91 nautical miles $(7.24 \mathrm{~km})$. After the marine vessel passes the inner basin at Port Aransas, it enters the Corpus Christi bay, approximately 18.14 nautical miles long $(33.60 \mathrm{~km})$, where they reduce their speed to about $12 \mathrm{knots}\left(6.17 \mathrm{~m} \cdot \mathrm{s}^{-1}\right)$. For calculation purposes, this segment was divided into Bay 1 and Bay 2 . Vessels going to La Quinta channel travel only Bay 1 while others going to inner harbor travel Bay 1 and Bay 2. Once the marine vessel reaches the Harbor Bridge, at the outer edge of the inner harbor, it further reduces its speed to about 5 knots $\left(2.57 \mathrm{~m} \cdot \mathrm{s}^{-1}\right)$. Since the marine vessel enters the port limits it is assisted by towboats/tugs while traveling to their berthing dock. La Quinta segment is where several private docks are located and is about midway in the ship channel. OGV going to La Quinta channel reduces its speed to $5 \mathrm{knots}\left(2.57 \mathrm{~m} \cdot \mathrm{s}^{-1}\right)$ and are assisted by towboats/tugs while traveling to their berthing dock. The distance traveled by the vessels varies as per the location of the docks. The Inner harbor and La Quinta channel is 7.50 nautical miles $(13.89 \mathrm{~km})$ and 4.88 nautical miles $(9.04 \mathrm{~km})$ long, respectively.

\section{Methods and Data}

\subsection{Emissions Estimation}

Emissions from marine diesel engines are significant contributor to air pollution in coastal areas and ports. 
Table 1. Summary of Corpus Christi ship channel segments.

\begin{tabular}{|c|c|c|c|c|}
\hline Segment & Segment Name & From/To & Nautical Miles & Speed \\
\hline 1 & Gulf & Outer Limit of Federally Dredged Channel to Inner Basin & 3.91 & 20 knots or max. speed \\
\hline 2 & Corpus Christi Bay 1 & Inner Basin up to La Quinta Junction & 8.48 & 12 knots \\
\hline 3 & Corpus Christi Bay 2 & La Quinta Junction to CC Harbor Bridge & 9.66 & 12 knots \\
\hline 4 & Inner Harbor & Harbor Bridge to Viola Basin & 7.50 & 5 knots \\
\hline 5 & La Quinta Channel & La Quinta Junction to La Quinta Basin & 4.88 & 5 knots \\
\hline
\end{tabular}

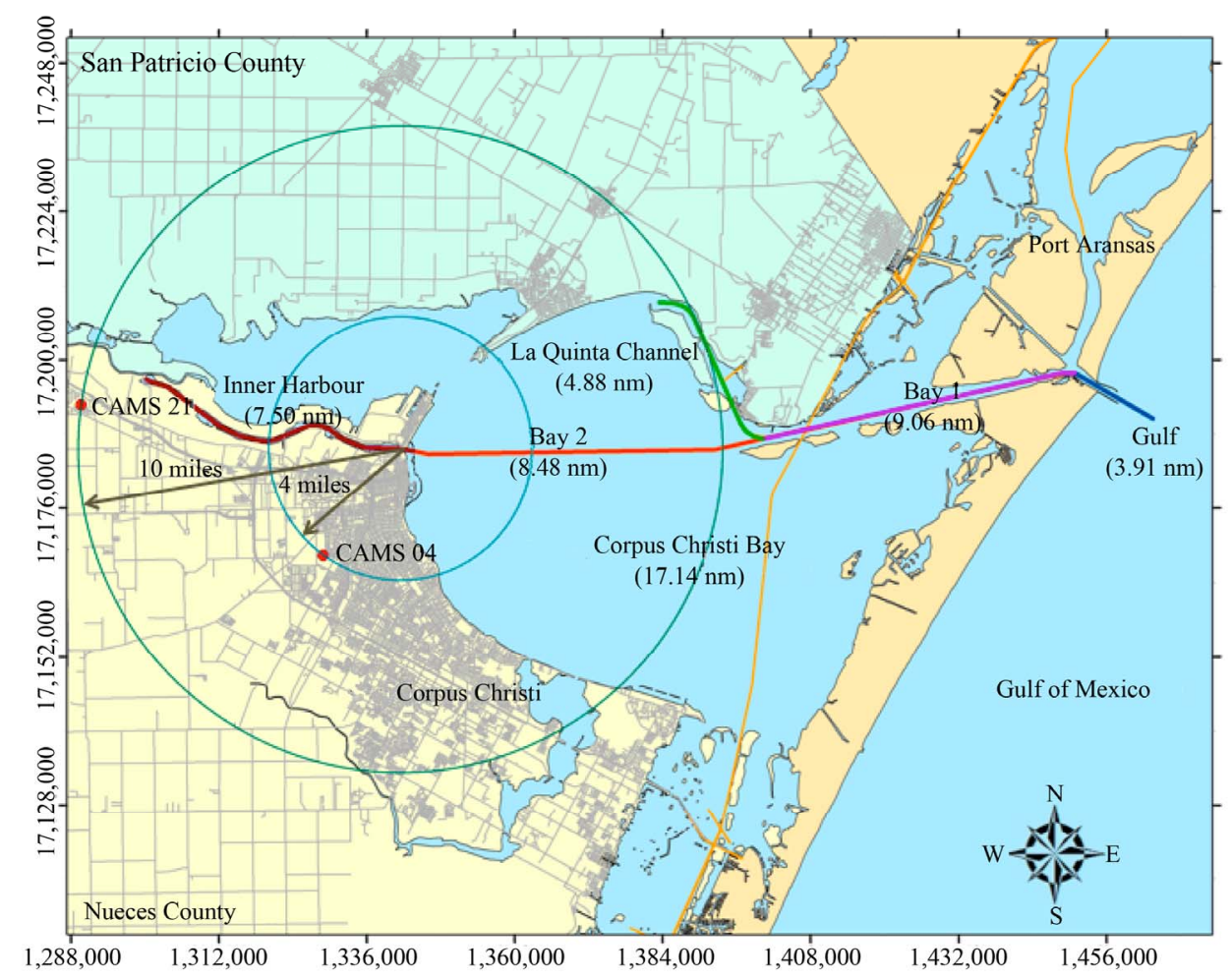

Figure 1. Corpus Christi ship channel segments.

Diesel engines on OGVs such as container ships, tankers, bulk carriers, and cruise ships are of two types-1) main propulsion engine and 2) auxiliary engines. The main propulsion engines are usually very large on most oceangoing vessels and are usually classified as "Category 3" engines. The engines on ocean-going vessels are typically with per-cylinder displacement of up to 30 liters and are usually classified as "Category 1" or "Category 2 " engines [26]. The emission calculations were based on the vessel activities, ship details, and EPA recommended methodology as shown in Figure 2.

The emissions were calculated by the product of the vessel trips or calls, vessel power, load factor, and time in the mode of operation for all modes of operation. Equation (1) was used to calculate emissions from vessels' main and auxiliary engines as shown below. Power required for each vessel was calculated for each segment as shown in Figure 1. The load factor to the main engine during each segment was calculated by using Equation (2) given below:

$$
E_{i}=\frac{E F_{i} \times P \times L F \times t}{453.57 \frac{g}{l b} \times 2000 \frac{l b}{t o n}}
$$

where, $E_{i}$ is emission of pollutant $i$ in transit segment in tons, $P$ is rated power of propulsion engine by vessel and engine type, $E F_{i}(\mathrm{~g} / \mathrm{kW}-\mathrm{hr})$ is emission factor for pollutant $i, L F$ is load factor (fraction of rated power) by mode, $t(\mathrm{hr})$ is average time for each mode by vessel and engine type per call or trip. The load factor calculation for the main engine is shown in Equation (2), while the load factor for the auxiliary engines were adopted from EPA [27] and are shown in Table 2.

$$
\text { Load Factor }=\left(\frac{\text { Actual Speed }}{\text { Cruise Speed }}\right)^{3}
$$

The main and auxiliary engine emission factors adopted in this study were reported in US EPA [27]. 
Table 2. Auxiliary engine load factor assumption [27].

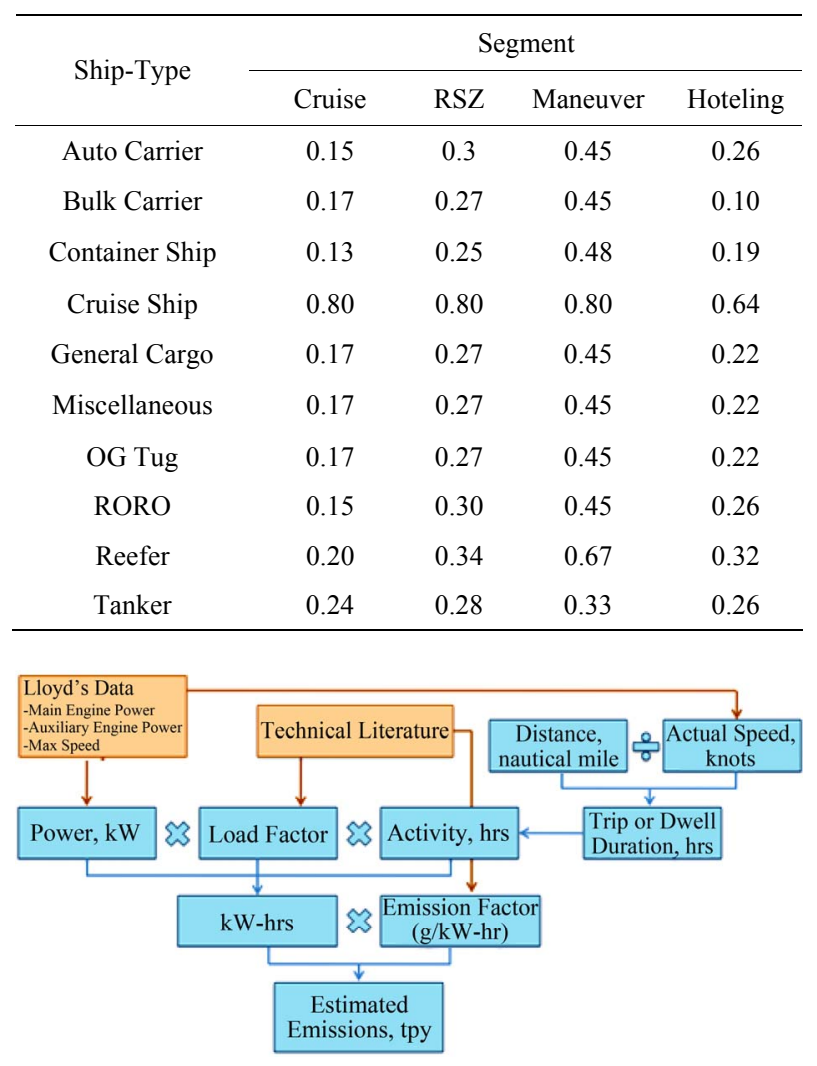

Figure 2. Marine engine emissions estimation flow chart.

Emission factors for slow-speed diesel (SSD), mediumspeed diesel (MSD), high-speed diesel, steam turbines (ST), and gas turbines (GT) for residual oil fuel were used in the study as shown in Table 3. At the dock, the auxiliary engines were assumed to operate at capacity for the duration of stay. This assumption was made from reports for the calculation of emissions from auxiliary engines [27]. It was also assumed that the main engine was completely shut down while hoteling. Barges are moved by tugboats. For barges in the ship channel, emissions were calculated for transit emissions only, although data from the Port shows the dock arrival and departure times. Emissions for each barge were calculated by assuming that each barge has a $1059 \mathrm{hp}$ engine.

\subsection{Data and Acquisition}

The Port of Corpus Christi Authority (PCCA) provided the vessel traffic data for total number of calls for the base year 2006-2009. The data was then compiled in a database using ship name and ID number, arrival/departure dates and times for each trip, deadweight, gross weight tonnages, and other ship information such as beam, length, and depth for each ship (these were not used in the calculations), ship cargo type, dock where the vessel was loaded or unloaded during each trip. Each
Table 3. Main and auxiliary engine emission factors $(\mathrm{g} / \mathrm{kW}$ hr) [27].

\begin{tabular}{ccccccccccc}
\hline \multirow{2}{*}{$\begin{array}{c}\text { Engine } \\
\text { Type }\end{array}$} & \multicolumn{8}{c}{ Emission Factors, $\mathrm{g} / \mathrm{kW}-\mathrm{hr}$} \\
\cline { 2 - 10 } & $\mathrm{NO}_{\mathrm{x}}$ & $\mathrm{PM}_{10}$ & $\mathrm{PM}_{2.5}$ & $\mathrm{HC}$ & $\mathrm{CO}$ & $\mathrm{SO}_{\mathrm{x}}$ & $\mathrm{CO}_{2}$ & $\mathrm{CH}_{4}$ & $\mathrm{~N}_{2} \mathrm{O}$ \\
\hline $\mathrm{SSD}$ & 18.1 & 1.42 & 1.31 & 0.6 & 1.4 & 10.29 & 620.62 & 0.006 & 0.031 \\
$\mathrm{MSD}$ & 14.0 & 1.43 & 1.32 & 0.5 & 1.1 & 11.24 & 677.91 & 0.004 & 0.031 \\
$\mathrm{GT}$ & 6.1 & 1.47 & 1.35 & 0.1 & 0.2 & 16.10 & 970.71 & 0.002 & 0.08 \\
$\mathrm{ST}$ & 2.1 & 1.47 & 1.35 & 0.1 & 0.2 & 16.10 & 970.71 & 0.002 & 0.08 \\
Auxiliary & 14.7 & 1.44 & 1.32 & 0.4 & 1.1 & 11.98 & 722.54 & 0.008 & 0.031 \\
\hline
\end{tabular}

marine vessel has its specification and the information for each vessel was extracted from Lloyd's Register of Ships [20]. The following information for each ocean going vessel was extracted: ship main engine brake horse power, auxiliary generator power, and maximum speed.

The ship activity data obtained from PCCA was further enhanced for emissions calculation by employing information such as year of build, speed (knots), main and auxiliary engine power $(\mathrm{kW})$ from the Register of Ships [20]. The information on some ships was not available and many ships were not in the Register of Ships database and were considered as missing. The percentage of missing ship information from the Register of Ships for the years of 2006-2008 was about $18 \%$ and it was $16 \%$ for 2009 . In order to fill in the missing ship information; first, the group identifier of the ship was noted; second, the average of the missing field for the group was calculated and used to replace the missing value. For example, if a crude oil tanker (COT) had no information on the maximum speed, then the average of maximum speed of all COTs was used. However, if the ship group was missing along with other field(s), then first the ship was grouped as "other Ship" and the remaining missing field(s) was calculated using the method described above.

\subsection{Photochemical Modeling}

The Comprehensive Air quality Model with extensions (CAMx) version 5.30 [24] was used to characterize the high ozone episode during September 2002. CAMx simulate the emissions, dispersion, chemical reactions, and removal of pollutants in the lower troposphere by solving the pollutant continuity equation for each chemical species on a system of nested three-dimensional grid system. The model was employed to simulate the high ozone episode of September 8-16, 2002. The first three days (Sep 8-10, 2002) were provided as ramp-up days for the model runs. The model performance for the 2002 base episode was evaluated and the results were observed to be within the limits prescribed by EPA [19].

The photochemical model has three modeling domains over the study region. The coarser grid has $45 \times 46$ cells 
with a grid resolution of $36 \mathrm{~km}$. This grid covers south, southwest and central portion of the US which includes Oklahoma, Mississippi, and Tennessee. The regional emissions grid has $87 \times 87$ cells with a $12 \mathrm{~km}$ grid resolution. This domain includes the urban areas of HoustonGalveston area, Beaumont-Port Arthur, Dallas-Fort Worth and all of the area in eastern Texas. The NNA grid consists of $90 \times 108$ cells with a $4 \mathrm{~km}$ grid resolution. It covers all the near non-attainment areas of central and south Texas including Austin, San Antonio, Victoria and Corpus Christi. The modeling domain used in this base case analysis is shown in Figure 3.

Emission sensitivity analysis was performed in order to find the impact of marine engine emissions within and around the urban airshed by conducting "zero-out" runs in which emissions from marine engines and barges were completely removed from the processed emissions input to the photochemical model with the help of associated model tools and user developed software. The influence of various emission source categories on the peak $\mathrm{O}_{3}$ levels were then calculated by subtracting the peak $\mathrm{O}_{3}$ concentrations for each particular zero-out run from the episode maximum $\mathrm{O}_{3}$ concentrations of the base case. First and higher order DDM analysis tool was used to determine the ozone sensitivity coefficients for $\mathrm{NO}_{\mathrm{x}}$ and $\mathrm{VOC}$ emissions from the marine engines.

\subsection{Emissions Preprocessing}

The 2002 emission inventory of all near non-attainment areas was processed using Emission Preprocessing System version 3.20 [28]. EPS3 processes emissions temporally and spatially to generate CAMx ready input files. The locations of the processed point sources of emissions are defined in terms of latitude and longitude. All other emission sources like area, non-road and on-road mobile and biogenic exist in the surface layer. In 2007 maximum numbers of OGV and barges calls were observed and as a result significant ozone precursor emissions were expected. The quantified emissions of OGV and barges for 2007 were then processed for transit and hoteling in two distinct steps; initially PRESHP (PRE process or for SHiPping emissions) module of EPS3 incorporated shipping emissions estimates within shipping lanes into the modeling domain. Its function was to identify the shipping channels within the modeling domain, spatially allocate shipping channel emissions to grid cells, and then reformat the shipping emissions estimates into the CAMx model ready format. Spatially allocated OGV and barges $\mathrm{NO}_{\mathrm{x}}$ emissions during transit and hoteling are shown in Figure 4.

\subsection{Meteorological Modeling}

Photochemical model CAMx requires hourly three di-

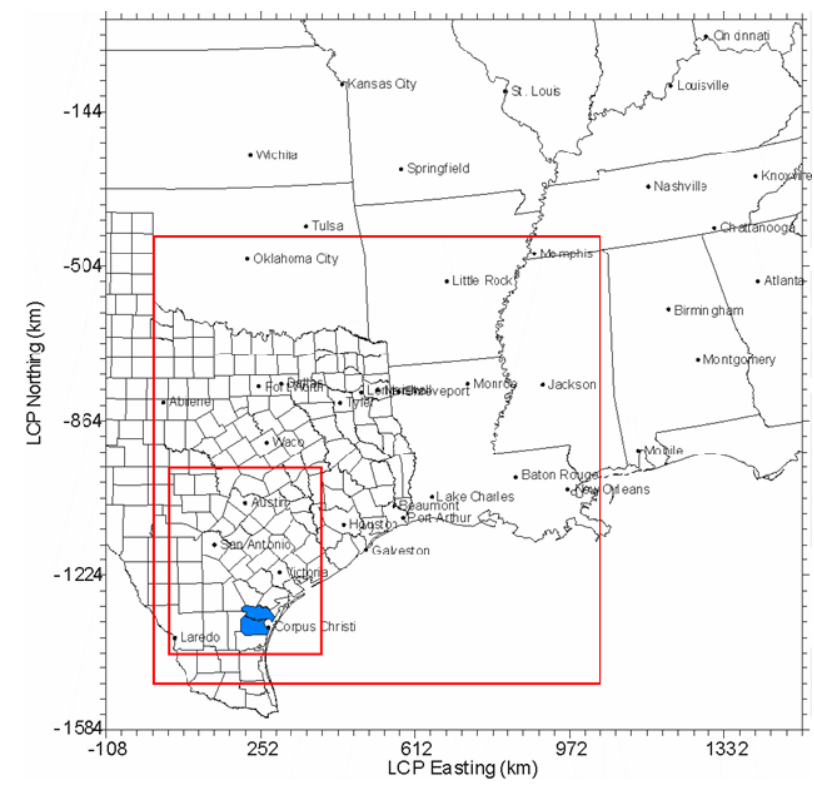

Figure 3. Modeling domain for near non-attainment areas of central and south Texas.

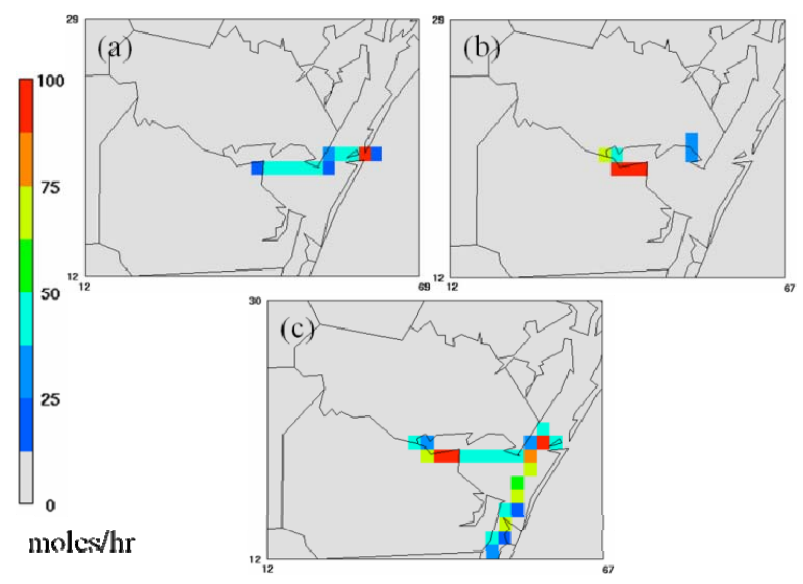

Figure 4. 2007 OGV NO emissions during (a) transit mode (b) hoteling mode and (c) barges emissions.

mensional meteorological parameters, namely layer interface height, winds, temperature, pressure, vertical diffusivity, water vapor, cloud cover, and rainfall rate. These meteorological inputs for CAMx model were generated using the Fifth Generation Pennsylvania StateUniversity/National Center of Atmospheric Research (PSU/NCAR) Meteorological Model (MM5) [29]. Meteorological inputs for Sep 8-16, 2002 were developed using MM5 and evaluated as per EPA criteria [19]. The model performed well within the acceptable limits set by EPA.

\section{Results and Discussion}

\subsection{Emissions from OGV and Barges}

The vessel activity data shown in Table 4 indicated that 
Table 4. Summary of distribution of number of calls by vessel type at PCCA during 2006-2009.

\begin{tabular}{ccccccccccc}
\hline Year & Tanker & Containers & Bulk Carrier & Cruise & Auto Carrier & General Cargo & RORO & Others & OGV Total & Barges \\
\hline 2006 & 973 & 44 & 269 & 566 & 3 & 52 & 0 & 86 & 1993 & 4666 \\
2007 & 908 & 0 & 291 & 768 & 1 & 74 & 0 & 98 & 2140 & 4627 \\
2008 & 1024 & 0 & 344 & 227 & 5 & 78 & 0 & 79 & 1757 & 4300 \\
2009 & 926 & 35 & 5 & 0 & 5 & 32 & 1 & 61 & 1315 & 3850 \\
\hline
\end{tabular}

the number of unique calls at PCCA peaked during 2007 and declined during the following two years. The decline could be attributed to the recent economic downturn since 2008. Since emissions are directly proportional to the number of calls at the port, thus the emissions during 2007 were expected to be maximum based on the number of unique calls. Table 4 shows that tankers accounted for maximum number of calls during 2006-2009. The estimates of marine engine emissions from OGVs for the PCCA during 2006-2009 for ozone precursors, criteria pollutants, and green house gases in tons per year (tpy) are summarized below in Tables 5 and $\mathbf{6}$. Since the numbers of unique calls during 2007 were observed to be highest, the emissions estimates were also highest for ozone precursors, criteria pollutants, and greenhouse gases. Figure 5 shows the trend of $\mathrm{NO}_{\mathrm{x}}$ and VOC emissions from ships during 2006-2009 at the PCCA. The ship traffic varied considerably during 2006-2009. During 2006 and 2007 a steady increase in the ship traffic was observed with peak number of calls of 2140 during 2007. This was followed by a sharp decrease in the ship traffic during 2008 and 2009 at the PCCA. This steady decrease in the number of calls and emissions due to the recent economic downturn resulted in lower ozone precursor, criteria pollutants, and green house gas emissions. The maximum reduction in emission was observed during 2009 when the number of calls decreased by about $38 \%$. These decreases lead to about 51\% decrease in ozone precursor, criteria pollutants, and green house gases emissions during 2009 as shown in Tables 5 and $\mathbf{6 .}$ This clearly suggested that the economic downturn had a significant impact on the overall emissions from marine $\mathrm{NO}_{\mathrm{x}}$ and VOC emissions from OGVs at the PCCA. Since the unique number of calls was highest during 2007, the ozone precursor, criteria pollutants, and greenhouse gases emissions were also highest during this time. Amongst the mode of ship transportation, hoteling contributed more than $50 \%$ of the total $\mathrm{NO}_{\mathrm{x}}$ emissions as shown in Figure 6.

The emissions from tugboats pushing barges at the PCCA and in the intercostal waterway were calculated using the EPA methodology. For the barges, unlike the OGVs, unique number of calls peaked during 2006 and steadily decreased thereafter through 2009 as shown in Table 4. Although, barges on an average accounted for about $70 \%$ of the total calls from 2006-2009; the emissions from barges were lower than from OGVs. This was
Table 5. Summary of criteria pollutants emissions from OGV and barges during 2006-2009.

\begin{tabular}{cccccccc}
\hline Class & Year & $\begin{array}{c}\mathrm{NO}_{\mathrm{x}} \\
\text { (tons) }\end{array}$ & $\begin{array}{c}\mathrm{PM}_{10} \\
\text { (tons) }\end{array}$ & $\begin{array}{c}\mathrm{PM}_{2.5} \\
\text { (tons) }\end{array}$ & $\begin{array}{c}\mathrm{HC} \\
\text { (tons) }\end{array}$ & $\begin{array}{c}\mathrm{CO} \\
\text { (tons) }\end{array}$ & $\begin{array}{c}\mathrm{SO}_{\mathrm{x}} \\
\text { (tons) }\end{array}$ \\
\hline \multirow{6}{*}{ OGV } & 2006 & 1699 & 152 & 140 & 51 & 129 & 1194 \\
& 2007 & 2057 & 187 & 172 & 60 & 156 & 1479 \\
& 2008 & 1467 & 131 & 121 & 44 & 111 & 1029 \\
& 2009 & 993 & 88 & 81 & 30 & 75 & 693 \\
& 2006 & 625 & 49 & 45 & 21 & 48 & 356 \\
& 2007 & 623 & 49 & 45 & 21 & 48 & 354 \\
& 2008 & 583 & 46 & 42 & 19 & 45 & 331 \\
& 2009 & 523 & 41 & 38 & 17 & 40 & 297 \\
\hline \multirow{6}{*}{ Barges }
\end{tabular}

Table 6. Summary of GHGs emissions from OGV and barges during 2006-2009.

\begin{tabular}{cccccc}
\hline Class & Year & $\begin{array}{c}\mathrm{CO}_{2} \\
\text { (tons) }\end{array}$ & $\begin{array}{c}\mathrm{CH}_{4} \\
\text { (tons) }\end{array}$ & $\begin{array}{c}\mathrm{N}_{2} \mathrm{O} \\
\text { (tons) }\end{array}$ & $\begin{array}{c}\mathrm{CO}_{2} \text { Equivalent } \\
\text { (tons) }\end{array}$ \\
\hline \multirow{6}{*}{ OGV } & 2006 & 72,830 & 0.80 & 3.30 & 73,869 \\
& 2007 & 90,229 & 1.00 & 4.00 & 91,504 \\
& 2008 & 62,571 & 0.70 & 2.80 & 63,465 \\
& 2009 & 42,048 & 0.40 & 1.90 & 42,651 \\
& 2006 & 21,446 & 0.21 & 1.07 & 21,782 \\
& 2007 & 21,366 & 0.21 & 1.07 & 21,702 \\
& 2008 & 19,983 & 0.19 & 1.00 & 20,297 \\
& 2009 & 17,938 & 0.17 & 0.90 & 18,219 \\
\hline \multirow{6}{*}{ Barges }
\end{tabular}

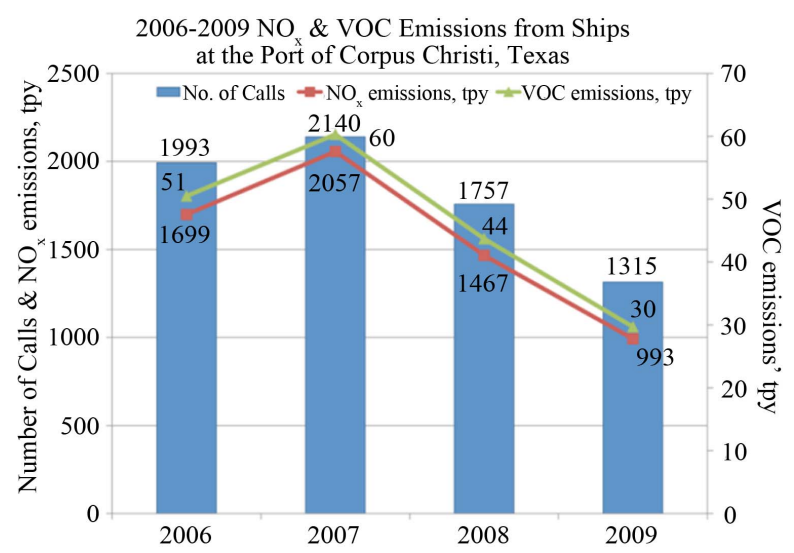

Figure 5. Number of OGV calls and quantified $\mathrm{NO}_{\mathrm{x}}$ and VOC emissions for the years 2006-2009. 

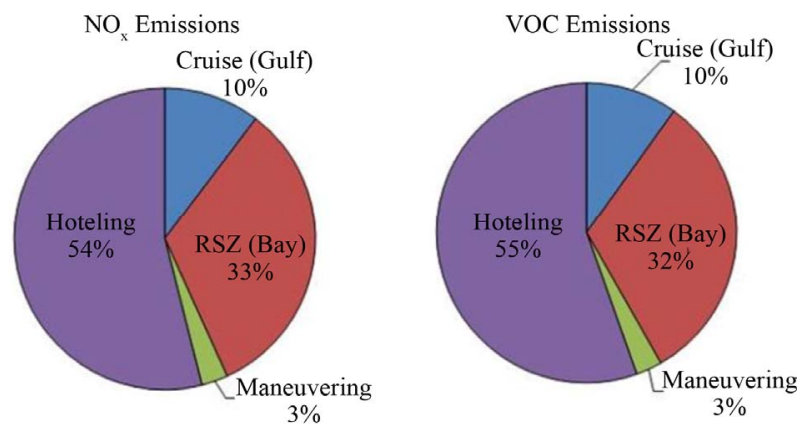

Figure 6. $2007 \mathrm{NO}_{\mathrm{x}}$ and VOC percent contribution in various segments of the Port of Corpus Christi.

because of the fact that barges use a smaller main enginewith an average power of $790 \mathrm{~kW}$ compared to the OGVs.

Tables 5 and $\mathbf{6}$ highlight the emissions from ozone precursors, criteria pollutants and greenhouse gases during 2006-2009 at the PCCA.

\subsection{Impact of Emissions from Marine Engines}

\subsubsection{Modeling the Impact of Marine Engines}

The developed base case model was evaluated as per EPA recommended statistical methods [30]. The archived surface observed ozone data were obtained from TCEQ for analysis purposes. The base case evaluation was done only for high ozone days of the episode which were September 11-14, 2002. The model was evaluated for the 8-hour ozone levels in all NNA. The base case model slightly under predicted the observed peak ozone levels. However, the unpaired peak accuracy for the study region was very much within $\pm 20 \%$ limits set by EPA.

Impact assessment of marine engine emissions within and around the urban airshed was conducted by "zero-out" runs in which emissions from marine engines and barges for transit and hoteling were completely removed from the emissions input to the photochemical model. Base case photochemical model for September 2002 was developed by replacing 2002 marine engine emissions with those calculated for 2007 as reported in this study. To find the impact due to marine engine emissions, a control case without emissions from OGV and barges during transit and hoteling was simulated. The impact of marine engine emissions on ozone levels was then calculated by subtracting the control case from the base case ozone concentrations. It was found that with the removal of OGV and barges emissions, the maximum hourly ozone concentration at the port and nearby area showed an increase of up to $8.45 \mathrm{ppb}$ as shown in Figure 7. The reason for the increase in the ozone concentration at the port and surrounding area was attributed to the absence of titration as a result of lack of fresh $\mathrm{NO}_{\mathrm{x}}$ emissions from OGV and barges. Furthermore, Figure 8

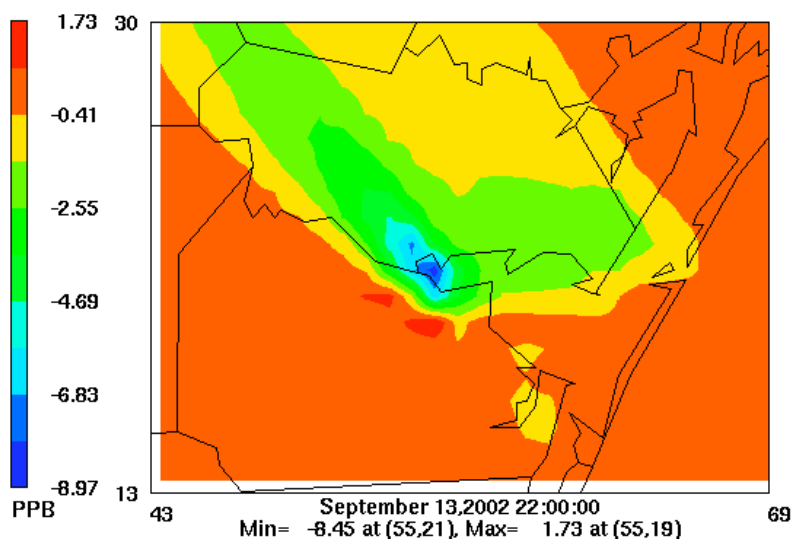

Figure 7. Hourly maximum impact on 8-hour ozone concentrations due to OGV and barge emissions within Corpus Christi urban airshed on Sep 13, 2002 at 10 PM.

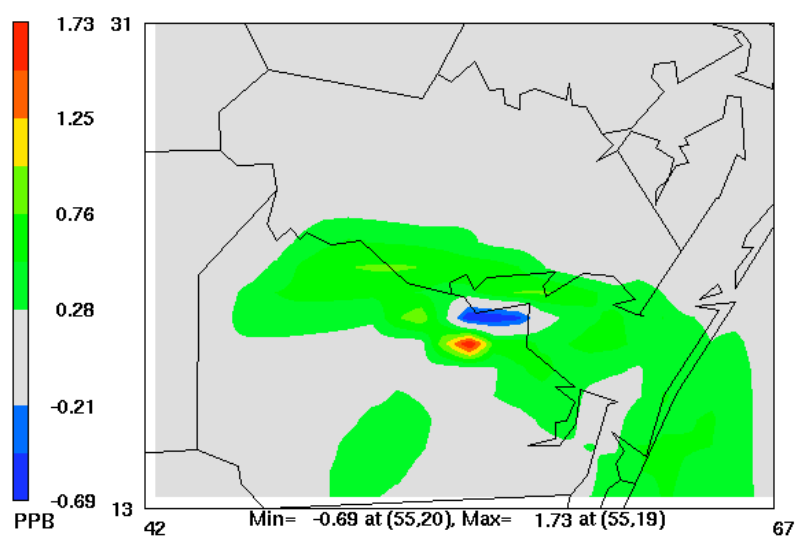

Figure 8. Maximum episodic impact on 8-hour ozone concentrations due to OGV and barge emissions within Corpus Christi urban airshed during Sep 11-13, 2002.

shows the maximum episodic impact unpaired with time, where the ozone concentration decreased by up to 1.73 ppb downwind. This represents the overall impact of the anthropogenic emissions from marine engines on the urban air quality.

\subsubsection{Impact of Hoteling Emissions}

For OGV emissions, hoteling contributed more than $50 \%$ of the total $\mathrm{NO}_{\mathrm{x}}$ emissions as shown in Figure 8. These contribute significantly to the total urban $\mathrm{NO}_{\mathrm{x}}$ emissions. A sensitivity analysis was conducted by "removing" hoteling emissions from the photochemical model to assess the maximum impact on the 8-hour ozone concentrations in the CCUA. The results showed a $0.45 \mathrm{ppb}$ and 1.31 ppb maximum increase and decrease (downwind) in the 8-hour ozone concentration as shown in Figure 9. The reason for the increase in the ozone concentration at the port was the absence of titration due to a lack of fresh $\mathrm{NO}_{\mathrm{x}}$ emissions and a subsequent decrease in the ozone concentration downwind was due to a reduced photochemical production as a result of lower $\mathrm{NO}_{\mathrm{x}}$ emissions. 


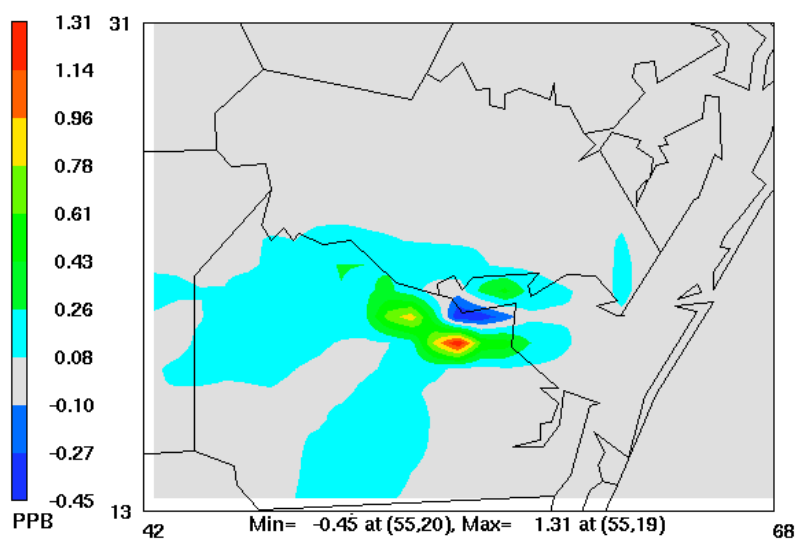

Figure 9. Impact on 8-hour ozone concentrations due to OGV hoteling emissions within Corpus Christi urban area.

\subsubsection{Impact of Fuel Types}

OGVs typically use "Residual oil" fuel, which has $2.7 \%$ sulfur contents. In this analysis, the impact of Marine Diesel Oil (MDO) with $1 \%, 0.5 \%$, and $0.1 \%$ of sulfur as an alternate fuel during transit as well as hoteling was under taken. This analysis was conducted in anticipation of an upcoming change in rule, which could require switching marine engine fuel to a cleaner fuel when a ship is within the maritime control of a port. For this analysis the emissions from each vessel during 2007 were recalculated with above mentioned fuel types. It was found that the use of MDO $1 \% \mathrm{~S}$ reduced $\mathrm{NO}_{\mathrm{x}}$ by 117 tons $(6 \%), \mathrm{PM}_{10}$ by 125 tons $(67 \%), \mathrm{PM}_{2.5}$ by $(66 \%)$, and $\mathrm{SO}_{\mathrm{x}}$ by $(65 \%)$ from $\mathrm{OGV}$ as shown in Table 7. However, further reduction in $\mathrm{NO}_{\mathrm{x}}$ emissions was not observed in case of MDO $0.5 \% \mathrm{~S}$ and $0.1 \% \mathrm{~S}$. Significant reduction in $\mathrm{PM}$ and $\mathrm{SO}_{\mathrm{x}}$ emissions were also observed with the use of the alternate fuel types. The impact analysis conducted using a photochemical model indicated that the change in fuel from residual oil to marine diesel oil with $1 \%$ sulfur had an insignificant impact of about $0.065 \mathrm{ppb}$ on the 8-hour ozone concentrations in the CCUA as shown in Figure 10. The impact on the ozone level due to fuel switching was also not significant, however it helped in reducing the overall burden of $\mathrm{NO}_{\mathrm{x}}$, $\mathrm{PM}$, and $\mathrm{SO}_{\mathrm{x}}$ emissions within the coastal urban area.

\subsubsection{Ozone Sensitivity Analysis}

The sensitivity of ozone formation was determined by implementing the DDM technique. In this analysis, the sensitivity of ozone to marine engine emissions was determined. First order ozone sensitivity coefficients due to $\mathrm{NO}_{\mathrm{x}}$ and VOC emissions along with the higher order sensitivity coefficients are shown in Figure 11. The DDM analysis has shown higher ozone sensitivity to $\mathrm{NO}_{\mathrm{x}}$ emissions than VOC emissions. $\mathrm{NO}_{\mathrm{x}}$ emissions from marine engines displayed the highest sensitivity coefficient of $1.25 \mathrm{ppb}$ in the northern and western re-
Table 7. 2007 annual OGV emissions with alternate fuel type.

\begin{tabular}{ccccccccc}
\hline $\begin{array}{c}\text { Fuel } \\
\text { Type }\end{array}$ & Sulfur & $\begin{array}{c}\mathbf{N O}_{\mathbf{x}} \\
\text { (tons) }\end{array}$ & $\begin{array}{c}\mathbf{P M}_{10} \\
\text { (tons) }\end{array}$ & $\begin{array}{c}\mathbf{P M}_{2.5} \\
\text { (tons) }\end{array}$ & $\begin{array}{c}\mathrm{HC} \\
\text { (tons) }\end{array}$ & $\begin{array}{c}\mathrm{CO} \\
\text { (tons) }\end{array}$ & $\begin{array}{c}\mathrm{SO}_{\mathbf{x}} \\
\text { (tons) }\end{array}$ & $\begin{array}{c}\mathrm{CO}_{2} \\
\text { (tons) }\end{array}$ \\
\hline $\mathrm{RO}$ & $2.7 \%$ & 2057 & 187 & 172 & 60 & 156 & 1479 & 90,229 \\
$\mathrm{MDO}$ & $1.0 \%$ & 1940 & 62 & 58 & 60 & 156 & 523 & 86,073 \\
$\mathrm{MGO}$ & $0.5 \%$ & 1940 & 41 & 38 & 60 & 156 & 261 & 86,073 \\
$\mathrm{MGO}$ & $0.1 \%$ & 1940 & 24 & 22 & 60 & 1567 & 52 & 86,073 \\
\hline
\end{tabular}

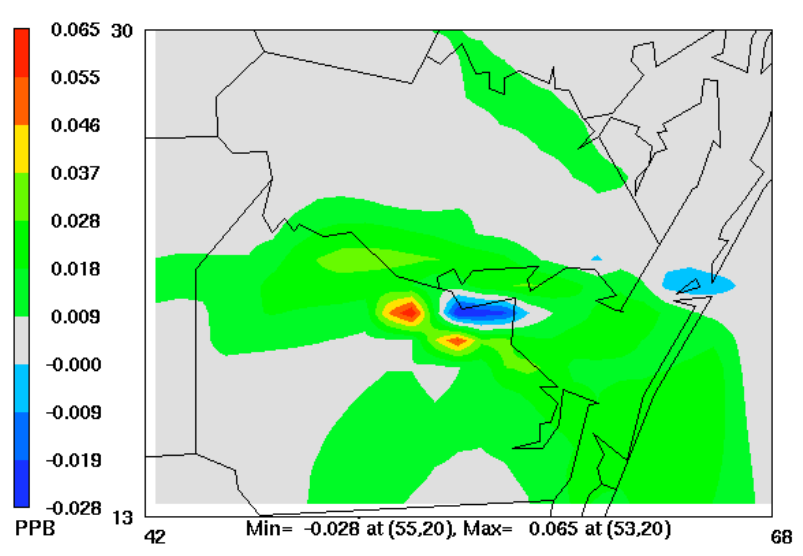

Figure 10. Impact on 8-hour ozone concentrations due to MDO 1\% S fuel usage within Corpus Christi urban area.

gions of the port while it showed a negative ozone sensitivity of $2 \mathrm{ppb}$ at the port as shown in Figure 11(a). Highest VOC sensitivity was observed to be at the port and in the surrounding bay area as shown in Figure 11(b). This suggests that reducing the VOC emissions from marine engines will marginally improve the ozone air quality in the urban airshed, and the control of $\mathrm{NO}_{\mathrm{x}}$ emissions will be far more beneficial for downwind areas further from the port than near the port premises.

\section{Conclusion}

A comprehensive assessment of the non-road emissions from OGV and barges in the Corpus Christi urban airshed was conducted in this study. The non-road mobile sources contributed approximately $27 \%$ of the $\mathrm{NO}_{\mathrm{x}}$ and $18 \%$ of the VOC emissions. The number of OGV calls peaked during 2007 and subsequently dropped in due to the recent economic downturn that started in 2008. It was also noted that $54 \%$ of the $\mathrm{NO}_{\mathrm{x}}$ emissions and $55 \%$ of the VOC emissions were emitted from OGV during hoteling operation. CAMx model was used to evaluate the impact of ozone precursor emissions by simulating a high ozone episode of September 8-16, 2002. From the zero-out emission runs, it was observed that the net impact of ozone precursor emissions from OGVs and barges on the urban peak 8-hour ozone levels was approximately 1.73 $\mathrm{ppb}$ within the airshed. Ozone sensitivity analysis using DDM on the 8-hour ozone concentrations showed a 

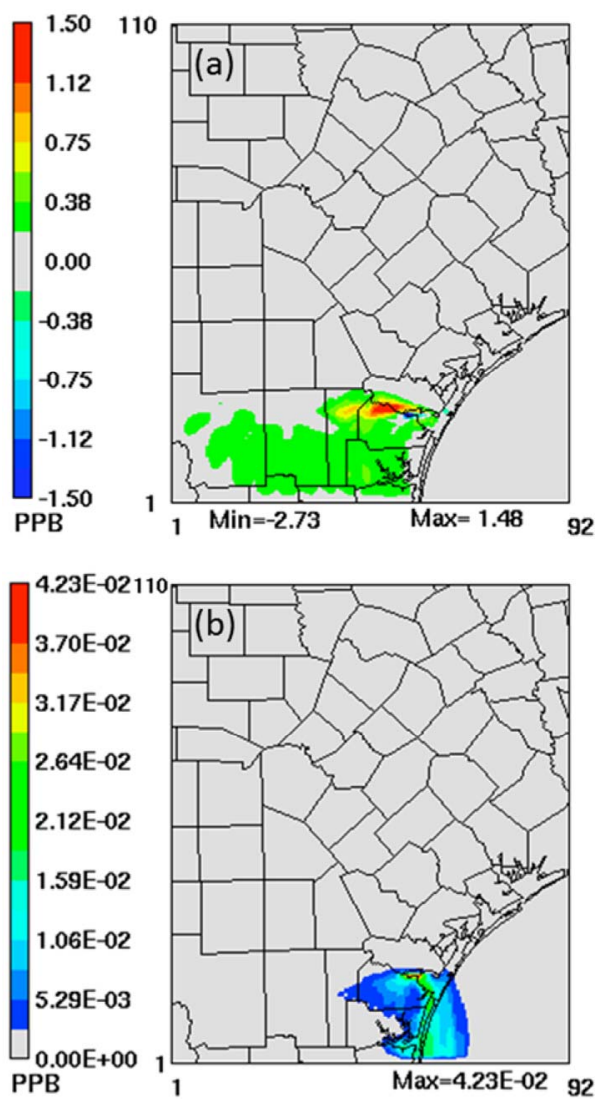

Figure 11. Daily maximum 8-hour average ozone sensitivity coefficient (derivatives) to anthropogenic $\mathrm{OGV}$ and barges emissions of (a) first-order $\mathrm{NO}_{\mathrm{x}}$ and (b) first-order VOC.

higher sensitivity to $\mathrm{NO}_{\mathrm{x}}$ emissions. Thus, any $\mathrm{NO}_{\mathrm{x}}$ related controls for marine engines will benefit the local and regional ozone levels. Results from this study, provides policy makers with the necessary approach to assess the impact of large emissions source categories in coastal urban airsheds with major port infrastructure and industrial operations.

\section{Acknowledgements}

This study was funded by research contracts from the Port of Corpus Christi and from the Texas Commission on Environmental Quality through a pass-through funding initiative titled "Rider 8 State of Texas Ozone Near Nonattainment Area Research and Planning Activities Funding Program". We would like to thank Ms. Sarah Garza, Environmental Compliance Manager at the Port of Corpus Christi, for providing us with the activities data for OGV and barges and for allowing access to the Lloyd's Ship of Registers.

\section{REFERENCES}

[1] J. J. Corbett and P. S. Fishbeck, "Emissions from Ships," Science, Vol. 278, No. 5339, 1997, pp. 823-824.

\section{doi:10.1126/science. 278.5339 .823}

[2] Q. B. Li, D. J. Jacob, I. Bey, P. I. Palmer, B. N. Duncan, B. D. Field, R. V. Martin, A. M. Fiore, R. M. Yantosca, D. D. Parrish, P. G. Simmonds and S. J. Oltmans, "Transatlantic Transport of Pollution and Its Effects on Surface Ozone in Europe and North America," Journal of Geophysical Research, Vol. 107, No. D13, 2002, pp. 41664186.

[3] Ø. Endresen, E. Sørgård, J. K. Sundet, S. B. Dalsøren, I. S. A. Isaksen, T. F. Berglen and G. Gravir, "Emission from International Sea Transportation and Environmental Impact," Journal of Geophysical Research, Vol. 108, No. D17, 2003, pp. 4560-4581. doi:10.1029/2002JD002898

[4] A. J. Dore, M. Vieno, Y. S. Tang, U. Dragosits, A. Dosio, K. J. Weston and M. A. Sutton, "Modelling the Atmospheric Transport and Deposition of Sulphur and Nitrogen over the United Kingdom and Assessment of the Influence of $\mathrm{SO}_{2}$ Emissions from International Shipping," Atmospheric Environment, Vol. 41, No. 11, 2007, pp. 23552367.

[5] D. A. Cooper, "Exhaust Emissions from High Speed Passenger Ferries," Atmospheric Environment, Vol. 35, No. 24, 2001, pp. 4189-4200.

[6] D. A. Cooper, "Exhaust Emissions from Ships at Berth," Atmospheric Environment, Vol. 37, No. 27, 2003, pp. 3817-3830.

[7] J. J. Corbett and H. W. Koehler, "Updated Emission from Ocean Shipping," Journal of Geophysical Research, Vol. 108, No. D20, 2003, pp. 4650-4665. doi:10.1029/2003JD003751

[8] J. J. Corbett and A. L. Robinson, "Measurements of $\mathrm{NO}_{\mathrm{x}}$ Emissions and In-Service Duty Cycle from a Towboat Operating on the Inland River System," Environmental Science \& Technology, Vol. 35, 2001, pp. 1343-1349.

[9] J. J. Corbett, P. S. Fishbeck and S. N. Pandis, "Global Nitrogen and Sulfur Inventories for Oceangoing Ships," Journal of Geophysical Research, Vol. 104, No. D3, 1999, pp. 3457-3470.

[10] C. Deniz and Y. Durmusoglu, "Estimating Shipping Emissions in the Region of the Sea of Marmara, Turkey," Science of Total Environment, Vol. 390, No. 1, 2008, pp. 255-261. doi:10.1016/j.scitotenv.2007.09.033

[11] J. Isakson, T. A. Person and E. S. Lindgren, "Identification and Assessment of Ship Emissions and Their Effects in Harbor of Göteborg, Sweden," Atmospheric Environment, Vol. 35, No. 21, 2001, pp. 3659-3666.

[12] U. Kesgin and N. Vardar, "A Study on Exhaust Gas Emission from Ships in Turkish Straits," Atmospheric Environment, Vol. 35, No. 10, 2001, pp. 1863-1870.

[13] E. Tzannatos, "Ship Emissions and Their Externalities for Greece," Atmospheric Environment, Vol. 44, No. 18, 2010, pp. 2194-2202.

[14] R. A. Duce, J. LaRoche, K. Altieri, K. R. Arrigo, A. R. Baker, D. G. Capone, S. Cornell, F. Dentener, J. Galloway, R. S. Ganeshram, R. J. Geider, T. Jickells, M. M. Kuypers, R. Langlois, P. S. Liss, S. M. Liu, J. J. Middelburg, C. M. Moore, S. Nickovic, A. Oschlies, T. Pedersen, J. Prospero, R. Schlitzer, S. Seitzinger, L. L. Sorensen, M. 
Uematsu, O. Ulloa, M. Voss, B. Ward and L. Zamora, "Impacts of Atmospheric Anthropogenic Nitrogen on the Open Ocean," Science, Vol. 320, No. 5878, 2008, pp. 893-897. doi:10.1126/science. 1150369

[15] J. J. Winebrake, J. J. Corbett, E. H. Green, A. Lauer and V. Eyring, "Mitigating the Health Impacts of Pollution from Oceangoing Shipping: An Assessment of Low Sulfur Fuel Mandates," Environmental Science \& Technology, Vol. 43, No. 13, 2009, pp. 4776-4782.

[16] M. Z. Farooqui, N. Sule and K. John, "An Evaluation of Anthropogenic Amissions in the Port of Corpus Christi, Texas," Proceedings of the A\&WMA 104th Annual Conference and Exhibition, Orlando, 21-24 June 2011.

[17] J. J. Corbett, "Emissions from Ships in the Northwestern United States," Environmental Science \& Technology, Vol. 36, No. 6, 2002, pp. 1299-1306.

[18] US Environment Protection Agency (USEPA), "Regulatory Announcement," 2010. http://www.epa.gov/oms/regs/nonroad/420f08004.htm

[19] M. Z. Farooqui, K. John, J. Biswas and N. Sule, "Modeling Analysis of the Impact of Anthropogenic Emission Sources on Ozone Concentration over Selected Urban Areas in Texas," Atmospheric Pollution Research, Vol. 4, 2013, pp. 33-42. doi:10.5094/APR.2013.004

[20] I. H. S. Fairplay, "Register of Ships 2010-2011," Lombard House, Surrey.

[21] M. G. Lawrence and P. J. Crutzen, "Influence of $\mathrm{NO}_{\mathrm{x}}$ Emissions from Ships on Tropospheric Photochemistry and Climate," Nature, Vol. 402, No. 6758, 1999, pp. 167170. doi:10.1038/46013

[22] E. Marmer and B. Langmann, "Impact of Ship Emissions on the Mediterranean Summertime Pollution and Climate: A Regional Model Study," Atmospheric Environment, Vol. 39, No. 26, 2005, pp. 4659-4669.

[23] S. Vutukuru and D. Dabdub, "Modeling the Effect of Ship Emissions on Coastal Air Quality: A Case Study of
Southern California," Atmospheric Environment, Vol. 42, No. 16, 2008, pp. 3751-3764.

doi:10.1016/j.atmosenv.2007.12.073

[24] ENVIRON International Corporation, “User's Guide for Comprehensive Air Quality Model with Extensions, CAMx Version 5.40," Novato, 2007, p. 306.

http://www.camx.com/files/camxusersguide_v5-40.aspx

[25] A. Hakami, M. T. Odman and A. G. Russell, "HigherOrder, Direct Sensitivity Analysis of Multidimensional Air Quality Models," Environmental Science \& Technology, Vol. 37, 2003, pp. 2442-2452.

[26] US Environmental Protection Agency (USEPA), "Commercial Marine Emissions Inventory for EPA Category 2 and 3 Compression Ignition Marine Engines in the United States Continental and Inland Waterways," EPA-420R-98-020, Office of Mobile Sources, Anne Arbor, 1998.

[27] ICF International, "Current Methodologies in Preparing Mobile Source Port-Related Emission Inventories: Final Report," prepared for US Environmental Protection Agency (USEPA), 2009, p. 116. http://www.epa.gov/cleandiesel/documents/ports-emissio n-inv-april09.pdf

[28] ENVIRON International Corporation, "User's Guide Emissions Processor Version 3.20 (EPS3)," ENVIRON International Corporation, Novato, 2010, p. 184.

[29] G. A. Grell, J. Dudhia and D. R. Stauffer, "A Description of the Fifth Generation Penn State/NCAR Mesoscale Model (MM5)," NCAR Tech. Note, NCAR/TN-398+ STR, Boulder, 1995, p. 122.

[30] US Environmental Protection Agency (USEPA), “Guidance on the Use of Models and Other Analyses in Attainment Demonstrations for the 8-hr Ozone NAAQS," EPA-454-R-05-002, Office of Air Quality Planning and Standards Emissions, Monitoring, and Analysis Division, Research Triangle Park, North Carolina, 2005. 